\title{
Risk Assessment in Financial Feasibility of Tanker Project Using Monte Carlo Simulation
}

\author{
Muhammad Badrus Zaman ${ }^{1}$, Dwi Priyanta ${ }^{2}$, Filik Trisilo ${ }^{3}$
}

\begin{abstract}
The inappropriate risk assessment process would have long-term impact, such as financial loss. Thus, risk and uncertainties analysis would be a very important process in financial feasibility determination of the project. This study analyzes the financial feasibility of 17,500 LTDW tanker project. Risk and uncertainty are two differentiated terminologies in this study, where risk focuses on operational risk due to shipbuilding process nonconformity to shipowner finance, while uncertainty focuses on variable costs that affect project cash flows. There are three funding scenarios in this study, where the percentage of funding with own capital and bank loan in scenario 1 is $100 \%: 0 \%$, scenario 2 is $75 \%: 25 \%$, and scenario 3 is $50 \%: 50 \%$. Monte Carlo simulation method was applied to simulate the acceptance criteria, such as net present value (NPV), internal rate of return (IRR), payback period (PP), and profitability index (PI). The results of simulation show that 17,500 LTDW tanker project funding by scenario 1, 2 and 3 are feasible to run, where probability of each acceptance criteria was greater than $50 \%$. Charter rate being the most sensitive uncertainty over project's financial feasibility parameters.
\end{abstract}

Keywords - financial feasibility, monte carlo simulation, risk event, tanker, uncertainty.

\section{INTRODUCTION}

1 anker is one of vessel types that is very important in the transportation of crude oil or product oil in the world. More than $50 \%$ of the world's oil movement use tankers through the sea. This can be observed through the map of global oil movement. It is noted that Hormuz Strait has approximately 17 million barrels oil movement per day and Malacca Strait has approximately 15.2 million barrels oil movement per day [1]. Even, $46 \%$ of the vessels passing through Malacca Strait are tankers [2]. Nevertheless, it turns out the existence of tankers has not been able to keep up with the crude oil demand globally [3]. Knowing this condition, the existence of tankers still needed to support the global oil movement.

However, determining the decision of tankers investment requires a detailed risk assessment process. Risk and uncertainties in capital cost, operating cost, bunker cost, freight rate, regulation and safety factors may be encountered during the project [4]. According to research, the consequences of regulatory changes in the maritime can causes financial impact about $5 \%$ of operational costs on tankers [5]. In addition, the uncertainty of material cost fluctuations also give financial impact in the chemical tanker building project (30,000 DWT). $75-80 \%$ of capital costs should be allocated for anticipate it. Althought, by estimating the project's uncertainties, that costs could be reduce about $9 \%$ [6].

The fuel cost uncertainty is a considerable cost. The percentage of this cost is up to $58 \%$ of the total cost [7]. In recent years, fuel prices have continued to rise along

Muhammad Badrus Zaman, Department of Marine Engineering, Institut Teknologi Sepuluh Nopember, Surabaya 60111, Indonesia, Email: druz_zaman@its.ac.id

Dwi Priyanta, Department of Marine Engineering, Institut Teknologi Sepuluh Nopember, Surabaya 60111, Indonesia, Email: priyanta@its.ac.id

Filik Trisilo, Department of Marine Engineering, Institut Teknologi Sepuluh Nopember, Surabaya 60111, Indonesia, Email: filik.trisilo@gmail.com with fluctuations in crude oil prices. Moreover tankers with voyage charter system still face the risk of a considerable fuel price [8]. This means that the uncertainty of fuel prices is still quite worrying.

The other research explain that delay on delivery until 74 days of tanker building project was categorise on high risk. The engineering, procurement and production stage predicted to cause delays on tanker delivery with probability 0.334 in the ship building industry subcluster Surabaya [9]. Thus, the assessment to analyze risks and uncertainties becomes important process in financial feasibility determination of tanker investment decisions.

Project financial feasibility would involve the calculation of some acceptance criteria, such as net present value (NPV), internal rate of return (IRR), payback period (PP), and profitability index (PI). By simulation method, the acceptance criteria is going to be generated as PDFs and CDFs.

Basically, investment decisions can be made by a commonly used deterministic method. However, the deterministic method proved to have weaknesses in predicting the conditions to come. In a deterministic method, cash flow was constructed based on the input of certain estimation values, when in fact they are an uncertainty that may be of different value in the future. As much as possible can be done is to make the values of uncertainty in a certain probability distribution [10] [11].

On the other hand, the simulation method is a method that can accommodate the assessment of risk and uncertainty quantitatively in the determination of project investment [12]. Monte Carlo simulation is one of the most applicable methods. This method is based on the iteration of repeating random numbers and is usually used to get a specific probability model forecast in solving a problem [13]. Thus Monte Carlo simulations can be applied to predict the financial feasibility of the project by considering risks and uncertainties.

Simulation steps for risk analysis in project financial feasibility based on the Monte Carlo simulation technique are as follows: define a quantitative model for the project investment considering all relevant input 
variables; estimate the probability density functions (PDFs) of every input variables; determine correlations cummulative distribution function (CDF) of the output variables (acceptance criteria); then statistical analysis and interpretation of the simulation result [14][30].

This study would discuss the financial feasibility of a 17,500 LTDW tanker project owned PT. Pertamina (Persero) Shipping by considering the risk and uncertainty based on the ship owner's point of view. This paper is grouped into four main sections. First, introduction that explains the background why this topic is worth to discuss. Second, the method that describes the stages to perform the analysis. Third, explains the result and discussion of the analysis. Fourth, explains the conclusion.

\section{METHOD}

The process in this study is shown in Figure 1. Risk events and uncertainty variables is being separated first. Risk events will be analyzed by probability and impact analysis, then represented in risk matrix. Uncertainty variables will be distributed by a certain PDFs, then formed as input to the cash flow of the tanker project. Monte Carlo simulation would be applied to obtain each probability of NPV $>0$, IRR $>7.83 \%, \mathrm{PP}<20$ years and $\mathrm{PI}>1$. Simulation is done to get CDFs of the acceptance criterias. Sensitivity analysis was done after simulation.

\section{A. Risk Identification}

Generally, the risk will occur if there is source and cause of risk and result in certain impact. Source of risk is inherent from within the system. While the cause of risk is a risk factor that is usually caused by external factors. How often these causes of risk occur can be analyzed by probability analysis. The impact of risk will arise when risk occurs, where risk is caused by a combination of source of risk with a cause of risk [15].

This study focuses on assessing operational risk aspects during shipbuilding process where it could affect the ship owner's financial condition when it occurs. In addition, potential cause of risk occurs also identified in this stage. The major potential causes of this risk obtained by interviews to Planning and Controlling between the input variables; calculate the PDF and

Department of PT. X shipyard.

\section{B. Probability Analysis}

Basically the probability calculation of an event in a system is done by various methods with different precision levels. But for more complex systems with more items, then by applying theoretical probability calculation method will be quite time consuming and exhausting. Thus the calculation through the approach method can be applied to speed up the completion. Although the precision level is lower, the calculation results with the approach still gives the error rate within acceptable limits [16]. This stage is aimed to determine probability value $(P)$ of each risk event by Upper Bound and Lower Bound approach.

If $C_{i}$ is a minimum cut set and $P\left(C_{i}\right)$ is the probability of $C_{i}$, so the failure probability of system by using Upper Bound and Lower Bound approach are given by the formula in Eqs (1) and (2).

$Q_{\text {Upper boutd }}={ }_{i=1}^{n} P\left(C_{i}\right)$

$Q s_{\text {Lowar boutad }}={ }_{i=1}^{n} P\left(C_{i}\right)-{ }_{i=2}^{n} \quad \begin{aligned} & i=1 \\ & j=1\end{aligned}\left(C_{i} \quad C_{j}\right)$

where, $C_{i}$ is a minimum cut set and $P\left(C_{i}\right)$ is the probability of $C_{i}$ given by $P\left(C_{1}\right)=Q_{1} \cdot Q_{2} \ldots Q_{\mathrm{n}}$ where $Q_{\mathrm{t}}$ is the failure probability of the item $n$ and $Q_{S}$ is failure probability of the system.

In this case, to define the probability of potential cause could be calculated from activities percentage of Work Breakdown Structure (WBS) of the new shipbuilding project.

\section{Impact Analysis}

Financial impact estimated in three point estimates, that are minimum (Min), most likely (ML), and maximum (Max) with an impact margin scenario. The impact rating shown in Table 1 , where BTR is the risk tolerance limit, taken $5 \%$ of CAPEX.

TABLE 1.

FinANCIAL IMPACT RATING (PT. PERTAMINA (PERSERo) SHIPPING)

\begin{tabular}{ccc}
\hline Financial impact range & Impact rating & Level \\
\hline $0-20 \%$ BTR & 1 & Insignificant \\
\hline $21-40 \%$ BTR & 2 & Minor \\
\hline $41-60 \%$ BTR & 3 & Moderate \\
\hline $61-80 \%$ BTR & 4 & Significant \\
\hline $81-100 \%$ BTR & 5 & Catastrophic \\
\hline
\end{tabular}




\section{Risk Repretentation at Risk Matrix}

Risk value is known by multiplying probability $(P)$ and impact $(I)$, i.e. risk score $=P x I$. Then, risk score is represented at the risk matrix. Based on the risk matrix representation, the level of each risk (very low, low, medium, high, very high) can be known. If the risks are in unacceptable category, avoidance, mitigation, or risk transfer is necessary.

\section{E. PDF Determination of Probability and Impact}

Probability values will be distributed using bernoulli distribution as Eqs (3), whereas impact will be distributed using triangular distribution as Eqs (4) [11] [17]. For the reason, that probability value would only give possibility of occurrence, it is perceived that bernoulli distribution is appropriate to be applied. While impact value are estimated in three point estimates, where the ML value lies between the Min and Max values, so impact was estimated using triangular distribution.

$f(x)= \begin{cases}1-p & \text { for } x=0 \\ p & \text { for } x=1\end{cases}$

where, $p$ is the mean value.

$f(x)=\left\{\begin{array}{l}\frac{2(x-a)}{(b-a)(a-a)}, a \leq x \leq c \\ \frac{2(b-x)}{(b-a)(b-a)}, c<x \leq b\end{array}\right.$

where, $a, b$ and $c$ denote the minimum, maximum and most likely values, and $p$ is the success probability of system.

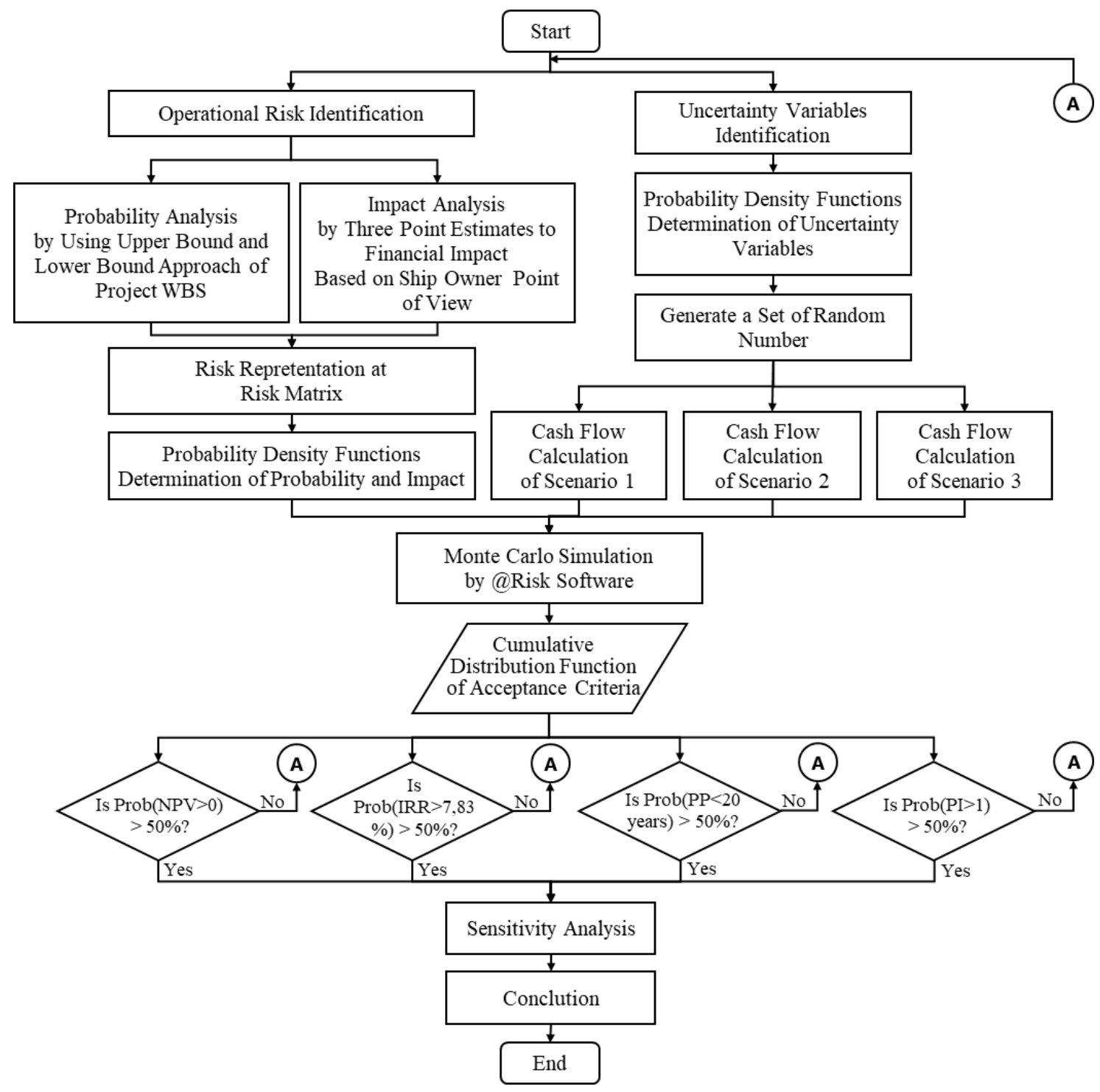

Figure. 1. Research Methodology

\section{F. Uncertainty Variable Identification}

The purpose of this stage is to determine uncertainty variables that are expected to be highly volatile over the life of the project investment in this case study. The uncertain variables mean as input factors to the cash flow of project. Assuming that the tanker would be functioned for voyage charters, so the cost variable that will affect the ship owner are like capital cost, operational cost, voyage cost, and periodic maintenance cost. The cargo handling cost is borne by the charterer [7]. 


\section{G. PDF Determination of Uncertainty Variable}

In general, PDF determination could be done by three approaches, those are real data distribution, empirical distribution and theoretical distribution function. The first approach could be done if there are large amounts of data. It will consuming extremely time, properly it is very hard to be realized. The second approach is obtained by grouping the real data to frequency histogram into a simulation model. However, incomplete data cause it so difficult. In contrast, a theoretical distribution function using heuristic procedures will take extreme values into account and timesaving procedure in performing simulations [18]. So, the last approach is commonly used.

The most commonly used PDFs for quantitative risk analysis in project management and finance term are uniform distribution, lognormal, bernoulli distribution and triangular distribution [11]. The PDF of uniform and lognormal distribution is described as Eqs (5) and Eqs (6) [17].

$f(x)=\frac{1}{b-a}$

$f(x)=\frac{1}{w \sqrt{2 \pi} \ln (\sigma)} e^{-\frac{\left[\ln [x]-\ln [y]^{2}\right.}{2\left[\ln [\varepsilon ;]^{2}\right.}}$

where, $a$ and $b$ denote the minimum and maximum values, $\mu$ is mean and $\sigma$ is standard deviation.

\section{H. Generate a Set of Random Number}

Random numbers are obtained by various sampling method, for example by random number table in general literature or by simulation software. The most important matter is the randomness of these numbers must be guaranteed. In this case, the help of simulation software by Monte Carlo sampling to get random number was applied.

\section{Cash Flow Calculation}

The cash flow is divided into four parts, namely the initial, operational, terminal, and net cash flow. The initial cash flow would be related to the CAPEX. The operational cash flow would be related to earning, OPEX, depreciation, Earning Before Interest Tax Depreciation and Amortation (EBITDA), tax, and Earning After Tax (EAT). Terminal cash flow would be related to the salvage value of the asset (usually considered as zero salvage value). While net cash flow would be related to loan repayment, discount factor, discounted cash flow and cumulative discounted cash flow [19][31].

OPEX variables are usually the most important to be considered. This is divided into three categories, i.e. operational costs and voyage costs which is described in Eqs (6) and (7), and periodic maintenance cost [7].

$$
O C_{\mathrm{t} m \mathrm{~m}}=M M_{\mathrm{t} m}+S T_{\mathrm{t} m}+M N_{\mathrm{t} m}+I_{\mathrm{t} m}+A D_{\mathrm{t} m}
$$

where, $O C_{t m}$ is operating cost, $M_{t m}$ is maning cost, $S T_{t m}$ is stores and consumable cost, $M N_{t m}$ is routine maintenance cost, $I_{t m}$ is insurance cost and $A D_{t m}$ is administration cost.

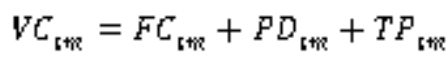

where, $V C_{t m}$ is voyage cost, $F C_{t m}$ is fuel cost for main engine and auxiliary engine, $P D_{t m}$ is port and light dues cost, and $T P_{t m}$ is tug and pilotage cost.

In operation, the ship's fuel consumption depends on its hull condition and the speed at which it is operated. Operation of the vessel at lower speeds results in fuel savings because of the reduced water resistance. Fuel consumption could be calculate by Eqs (8).

$F=F^{*}\left(\frac{s}{s}\right)^{\mathbb{Q}}$

where, $F$ is the actual fuel consumption (tons/day), $S$ the actual speed, $F^{*}$ the design fuel consumption and $S^{*}$ the design speed. The exponent $a$ has a value of about 3 for diesel engines and about 2 for steam turbines.

The acceptance criteria, such as NPV, IRR, PP and PI calculated by the Eqs (9), Eqs (10), Eqs (11) and Eqs (12). Project will be accepted if the value of NPV greater than 0 , IRR greater than $7.83 \%$, PP less than 20 years and PI greater than 1.

$$
\begin{aligned}
& N P V=\sum_{\mathrm{t}=\mathrm{D}}^{\mathrm{t}} \frac{(C F) \mathrm{t}}{(1+\mathrm{l})^{\mathrm{t}}}-\sum_{\mathrm{t}=\mathrm{D}}^{\mathrm{t}} \frac{\left(C_{Q}\right) \mathrm{t}}{(1+\mathrm{i})^{\mathrm{t}}} \\
& \sum_{\mathrm{t}=\mathrm{D}}^{\mathrm{n}} \frac{(C F) \mathrm{t}}{(1+i)^{\mathrm{t}}}-\sum_{\mathrm{t}=\mathrm{D}}^{\mathrm{n}} \frac{\left(C_{0}\right) \mathrm{t}}{\left(1+\hat{D}^{\mathrm{t}}\right.}=0 \\
& \sum_{\mathrm{t}=\mathrm{v}}^{\mathrm{n}} \frac{(C r) \mathrm{t}}{(1+i)^{\mathrm{t}}}-(C f)=0
\end{aligned}
$$

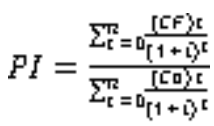

where, $n$ is tanker economic life time, $t$ is year, $C F$ is cash inflow, Co is cash outflow, $C f$ is initial cost and $i$ is rate of return.

\section{J. Monte Carlo Simulation}

This simulation stage requires help from @ Risk software. The simulation would be run up to 5,000 iterations with expected to get a model that is close to real conditions. The result from this simulation is CDF of each acceptance criteria. The probability of success of the acepptance criteria in the $50 \%$ to $100 \%$ range can be used as a reference in considering the feasibility of the project. This value is at a very likely level of certainty as shown in Table 2 [20]. If probability of acceptance criteria less than $50 \%$, project is not feasible. The literature review that apply the Monte Carlo simulation method in financial feasibility of project shown in Table 3. 
TABLE 2 .

A WAY TO STRUCTURE PROBABILITY OF OCCURRENCE

\begin{tabular}{cc}
\hline Degree of certainty & Probability \\
\hline Not likely & $<5 \%$ \\
\hline Less likely & $5 \%-20 \%$ \\
\hline Likely & $20 \%-50 \%$ \\
\hline Very likely & $50 \%-100 \%$ \\
\hline
\end{tabular}

TABLE 3.

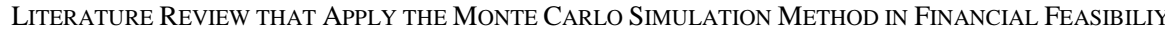

\begin{tabular}{|c|c|c|}
\hline No. & Authors & Result \\
\hline 1. & $\begin{array}{l}\text { (Liu, et al., } \\
\text { 2017) }\end{array}$ & $\begin{array}{l}\text { Monte Carlo simulation could estimate the financial feasibility of oil refinery project in Brazil. The } \\
\text { probability of NPV>0, before and after tax were } 54.1 \% \text { and } 51.4 \% \text {. Probabilityy of IRR }>13 \% \text {, before and } \\
\text { after tax were } 88.1 \% \text { and } 82.8 \% \text {. }\end{array}$ \\
\hline 2 & $\begin{array}{c}\text { (Chu, et al., } \\
\text { 2016) }\end{array}$ & $\begin{array}{l}\text { Monte Carlo simulations could be applied in the finance analyzing of Hydroprocessed Renewable Jet fuel } \\
\text { production with probability of IRR }>15 \% \text { were } 29 \%, 18 \%, 8 \% \text {, and the probability of NPV }>0 \text { were } 85 \% \text {, } \\
75 \%, 58 \% \text { respectively for camelina, carinata and used cooking oil. }\end{array}$ \\
\hline 3. & $\begin{array}{c}\text { (Saffie \& } \\
\text { Jaaman, 2016) }\end{array}$ & $\begin{array}{l}\text { Monte Carlo used on NPV for capital investment in Malaysia. It was an easy and practical technique that } \\
\text { could be used to improve NPV analysis. The results show the estimation of NPV constitute with the } \\
\text { uncertainty of the cash flows. }\end{array}$ \\
\hline 4. & $\begin{array}{l}\text { (Amigun, et al., } \\
\text { 2011) }\end{array}$ & $\begin{array}{l}\text { Monte Carlo used on economic risk assessment of advanced process technologies for bioethanol } \\
\text { production in South Africa. There were three scenario in this research. The result shows probability of } \\
\text { NPV }>0 \text { were } 93 \%, 98 \% \text { and } 96 \% \text { for each scenario. }\end{array}$ \\
\hline
\end{tabular}

\section{K. Sensitivity Analysis}

The sensitivity analysis aims to identify the most important input variables which lead to the greatest decrease of the output variables when it varied, and to reduce the number of unnecessary input variables which will not lead to significant reductions in the uncertainty of the output variables [21]. By knowing the sensitive variables, it will be able to provide input in planning the strategy in running the project.

Sensitivity analysis can be started after the simulation is done. This analysis will involve determining the correlation between input and output variables. The spearman correlation could be use. That is a statistical measure of the strength of a monotonic relationship between paired data. The calculation of Spearman correlation coefficient is described in Eqs (13).

$\rho=1-\left(\frac{6 \sum(\Delta R)^{2}}{t\left(n^{2}-1\right)}\right)$

where, $\rho$ is correlation coefficient, $\Delta R$ is rank difference betwen variables, $n$ is count of data.

Correlation is an effect size and verbally describe the strength of the correlation using the following guide in Table 4 for the absolute value of $\rho$ [22].

TABLE 4.

CORRELATION COEFFICIENTS

\begin{tabular}{lcc}
\hline Correlation & Negative & Positive \\
\hline Perfect correlation & -1 & 1 \\
\hline Significant correlation & $-0,75$ & 0,75 \\
\hline Good correlation & $-0,5$ & 0,5 \\
\hline Mild correlation & $-0,25$ & 0,25 \\
\hline No correlation & 0 & 0 \\
\hline
\end{tabular}




\section{RESULTS AND DISCUSSION}

This paper focuses on detailing the risk events and uncertainty variables that could affect financial feasibility of 17,500 LTDW tanker project. This part grouped intogeneral assumption, risk analysis, PDF of uncertainty variable, and simulation result.

\section{A. General Assumption}

As a support of analysis in this research, the ship sister data was needed as shown in Table 5. In this case, used data of MT. Pagerungan owned PT. Pertamina (Persero) Shipping.

The general assumption for financial feasibility calculation in this paper are:

1) Economic life: the economic life of tanker in this case is 20 years of operation, starting from July 2020.

2) Design and the construction phase: this paper assumes that the design and the construction phase would be finished for two and half years, starting from January 2018.

3) Depreciation method: this paper assumes a straight line depreciation starting from the first year of operation, with a zero salvage value.

4) CAPEX payment period: CAPEX payment period to shipyard is divided into three period with percentage are $20 \%, 40 \%$ and $40 \%$.

5) Tax: oil company tax is $25 \%$.

6) Scenario: there are three scanarios of project financing in this paper. The proportion with private fund and bank loan for each scenario are, first scenario $100 \%$ : $0 \%$, second scenario $75 \%$ : $25 \%$, and third scenario 50\%:50\%.
7) Bank interest rate: the bank loan are assumed with compound interest.

8) Acceptance criteria: the acceptance criterias of financial feasibility in this paper are $\mathrm{NPV}>0$, IRR $>7.83 \%, \mathrm{PP}<20$ years and PI $>1$. Project will feasible if probability of each criteria is greater than $50 \%$ based on simulation.

9) The vessel will be used for voyage charters where the cost of capital, operational costs and voyage costs are borne by ship owner.

10) Shipping route scenario: the ship route scenario is from Tanjung Sekong (Cilegon, Indonesia) - Port of Klang (Malaysia) - Belawan Port (Sumatera, Indonesia).

\section{B. Risk Analysis}

Based on risk analysis, the operational risk register in 17,500 LTDW tanker project shown in Table 6. The risk of delays in delivery of new vessels potentially lead to a disruption to the ship's voyage schedule, so that the shipowner must issue a replacement vessel rental fee due to a contract with the charterer. The risk of insufficient speed cause unsuitable of the voyage time. Beside that, lower design speed, will increase the fuel cost. Excessive fuel consumption lead to actual fuel consumption exceeds the design fuel consumption, so that the fuel cost increase. Insufficient dead weight tonnage potentially lead to lower cargo lifting amount. The risk of ships having off hire after delivery cause losses to ship's sailing time due to the time constrained for repair, so that revenue will decrease. The risk repretentation in risk matrix shown in Figure 2.

TABLE 5 .

SHIP SISTER DATA

\begin{tabular}{ccc}
\hline Item & Unit & Nominal \\
\hline Ship name & - & MT. Pagerungan (product oil tanker) \\
\hline Deadweight & LTDW & 17,500 \\
\hline L x B x H & $\mathrm{m}$ & $149.50 \times 27.70 \times 12.00$ \\
\hline Draught & $\mathrm{m}$ & 7.00 \\
\hline Cont. max. speed & $\mathrm{knot}$ & 13.39 \\
\hline Service speed & $\mathrm{knot}$ & 12.5 \\
\hline Cargo capacity & $\mathrm{m}$ & 25,528 \\
\hline Main engine power & $\mathrm{kW}$ & 4,400 \\
\hline Main engine SFOC & $\mathrm{g} / \mathrm{kWh}$ & 179 \\
\hline Main engine SLOC & $\mathrm{g} / \mathrm{kWh}$ & 0.6 \\
\hline Aux. engine power & $\mathrm{kW}$ & 2,320 \\
\hline Aux. engine SFOC & $\mathrm{g} / \mathrm{kWh}$ & 185 \\
\hline Aux. engine SLOC & $\mathrm{g} / \mathrm{kWh}$ & 0.6 \\
\hline Number of crew & $\mathrm{person}$ & 7 \\
\hline
\end{tabular}


TABLE 6.

RISK REGISTER OF THE TANKER PROJECT

\begin{tabular}{lllllll}
\hline \multirow{2}{*}{ Code } & & \multicolumn{1}{c}{ Risk Event } & Prob. & \multicolumn{2}{c}{ Financial Impact (USD) } & Risk Level \\
\cline { 4 - 6 } & & & Min & ML & Max & \\
\hline R1 & Risk of delays in delivery of new vessel & 0.475644 & $(731,729)$ & $(6,343)$ & 562,984 & Very Low \\
\hline R2 & Risk of insufficient speed design & 0.009663 & 247,757 & 390,208 & 559,245 & Very Low \\
\hline R3 & Risk of excessive fuel consumption & 0.012198 & 112,987 & 197,343 & 266,662 & Very Low \\
\hline R4 & Risk of insufficient dead weight tonnage (DWT) & 0.004492 & 32,605 & 150,788 & 494,325 & Very Low \\
\hline R5 & Risk of tanker having off hire after a year delivery & 0.014133 & 30,000 & 115,000 & 300,000 & Very Low \\
\hline
\end{tabular}

\begin{tabular}{|c|c|c|c|c|c|}
\hline Prob. $(P)$ & \multicolumn{5}{|c|}{ Risk score $=P x I$} \\
\hline 6 & & & & & \\
\hline 5 & & & & & \\
\hline 4 & & & & & \\
\hline 3 & R1 & & & & \\
\hline 2 & & & & & \\
\hline 1 & $\begin{array}{c}\text { R3, } \\
\text { R4, R5 }\end{array}$ & $\mathbf{R 2}$ & & & \\
\hline & 1 & 2 & 3 & 4 & 5 \\
\hline
\end{tabular}

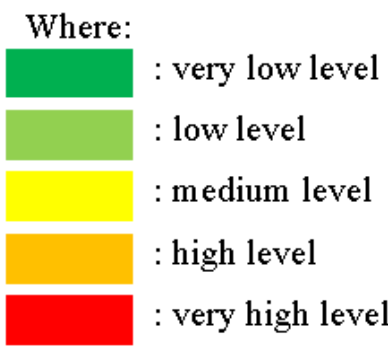

Figure. 2. Risk Repretentation in Risk Matrix

\section{PDF of Uncertainty Variable}

The uncertainty variables and its PDFs shown in Table X. The uncertainty variables was estimated in three point estimates, i.e. Min, ML and Max. Some variables could be assumed to be fixed, i.e. ship size is 17,500 LTDW, oil company tax is $25 \%$, vessel investment life time for 20 years and rate of returns $(i)$ is $7.83 \%$ [23].

The estimated value of CAPEX is based on PT. Pertamina (Persero) Shipping, ie minimum estimate is $22,676,469$ USD, most likely amounted to $23,869,967$ USD and maximum of 25,063,465 USD.

Estimated value of OPEX is based on several reference sources. Explanation of each variable cost is as follows:

1) Crew costs are the costs incurred for crew salaries, operational and insurance needs. With the number of crew is 7 people and the calculation estimate refers to the Peraturan Menteri Perhubungan No. 3 RI 2017, the most likely estimate for crew costs is 241,672 USD/year with $\pm 5 \%$ for min and max estimates.

2) Lubricating cost is calculated by referring to the price of lubricant in the range of 4,000 to 5,000
USD/ton and the change of lubricant is done once in a year, the estimated cost for main engine and auxiliary engine lubricant needs is minimum 114,728 USD/year and maximum 143,410 USD/year.

3) The cost of repair and maintenance is the estimated cost incurred for the maintenance of the ship (not including periodic maintenance). This cost value is estimated by referring to PT. Pertamina (Persero) Shipping where the cost of repair and maintenance for tanker 17,500 LTDW is $967 \mathrm{USD} / y e a r$. In this research, minimum and maximum repair and maintenance cost is estimated $\pm 5 \%$.

4) Insurance costs represent costs incurred for hull and machinery insurance and protection and Indemnity Insurance. Referring to PT. Pertamina (Persero) Shipping where the cost is 55,440 USD/year and 25,907 USD/year, the total cost of insurance is $81,347 \mathrm{USD} / y e a r$. In this study, the minimum and maximum insurance costs are estimated $\pm 2.5 \%$. 
TABLE 7

PDF AND ESTIMATION VALUE OF UNCERTAINTY VARIABLE

\begin{tabular}{|c|c|c|c|c|c|c|c|c|}
\hline \multirow{2}{*}{ No. } & \multirow{2}{*}{$\begin{array}{c}\text { Cost } \\
\text { category }\end{array}$} & \multirow{2}{*}{$\begin{array}{c}\text { Uncertainty } \\
\text { variable }\end{array}$} & \multirow{2}{*}{ Unit } & \multicolumn{3}{|c|}{ Estimation (USD) } & \multirow{2}{*}{ PDF } & \multirow{2}{*}{ Note } \\
\hline & & & & Min & ML & Max & & \\
\hline 1 & CAPEX & $\begin{array}{c}\text { Capital } \\
\text { Expenditure }\end{array}$ & USD & $22,676,469$ & $23,869,967$ & $25,063,465$ & Triangular & $\begin{array}{c}\text { Estimation (PT. } \\
\text { Pertamina (Persero) } \\
\text { Shipping) } \\
\end{array}$ \\
\hline \multirow[t]{8}{*}{2.} & \multirow[t]{8}{*}{ OPEX } & Crew cost & USD/year & 229,589 & 241,672 & 253,756 & Triangular & $\begin{array}{c}\text { Estimation } \\
\text { (Peraturan Menteri } \\
\text { Perhubungan No. } 3 \\
\text { RI tahun 2017) }+5 \%\end{array}$ \\
\hline & & $\begin{array}{c}\text { Lubricating } \\
\text { cost }\end{array}$ & USD/year & 114,728 & & 143,410 & Uniform & Estimation \\
\hline & & $\begin{array}{c}\text { Repair \& } \\
\text { maintenance } \\
\text { cost }\end{array}$ & USD/year & 919 & 967 & 1,015 & Triangular & $\begin{array}{c}\text { Estimation (PT. } \\
\text { Pertamina (Persero) } \\
\text { Shipping) with } \pm 5 \%\end{array}$ \\
\hline & & Insurance cost & USD/year & 79,313 & 81,347 & 83,381 & Triangular & $\begin{array}{l}\text { Estimation (PT. } \\
\text { Pertamina (Persero) } \\
\text { Shipping) with } \pm \\
2.5 \%\end{array}$ \\
\hline & & $\begin{array}{c}\text { Administration } \\
\text { cost }\end{array}$ & USD/year & 7,600 & 8,000 & 8,400 & Triangular & $\begin{array}{c}\text { Estimation with } \pm \\
5 \% \\
\end{array}$ \\
\hline & & Docking cost & USD/dock & 530,225 & 543,820 & 557,416 & Triangular & $\begin{array}{c}\text { Estimation (PT. } \\
\text { Pertamina (Persero) } \\
\text { Shipping) with } \pm \\
2.5 \%\end{array}$ \\
\hline & & Fuel cost & USD/year & $2,259,731$ & $2,466,793$ & $2,666,619$ & Triangular & $\begin{array}{c}\text { Empiris (Ship \& } \\
\text { Bunker 21 April } \\
\text { 2017; Bunker index } \\
\text { MDO 14 Juni 2017) }\end{array}$ \\
\hline & & Port charges & USD/year & $1,034,999$ & $1,040,554$ & $1,046,110$ & Triangular & (Pelindo I, 2004) \\
\hline \multirow[t]{4}{*}{3} & \multirow[t]{4}{*}{ Earning } & $\begin{array}{c}\text { Commisioning } \\
\text { day }\end{array}$ & days/year & 326 & 328 & 330 & Triangular & Estimation \\
\hline & & Charter rate & USD/day & 10,000 & 23,000 & 30,000 & Triangular & $\begin{array}{c}\text { Empiris (Sand, P., } \\
\text { 2017) }\end{array}$ \\
\hline & & $\begin{array}{l}\text { Bunker cost } \\
\text { saving }\end{array}$ & USD/year & $1,040,988$ & $1,136,375$ & $1,228,429$ & Triangular & Estimation \\
\hline & & $\begin{array}{c}\text { Port charges } \\
\text { saving }\end{array}$ & USD/year & 17,721 & 25,315 & 20,252 & Triangular & Estimation \\
\hline 4 & Other & Interest rate & $\% /$ year & 4.75 & 7.45 & 12.75 & Lognormal & $\begin{array}{l}\text { Empiris (Taborda, } \\
\text { 2017. Indonesia } \\
\text { Interest Rates } 2005 \\
-2017 \text { ) }\end{array}$ \\
\hline
\end{tabular}

5) Administration costs are allocated for ship correspondence, where the estimated administratition cost is approximately 8,000 USD/year, with minimum and maximum estimates being $\pm 5 \%$.

6) The docking cost is the cost incurred for ship docking, where docking estimates are only made during intermediate surveys and special surveys (2.5 years). The value of this cost is estimated by referring to PT. Pertamina (Persero) Shipping where the docking cost is $543,820 \mathrm{USD} /$ docking. In this study, minimum and maximum docking costs were estimated $\pm 2.5 \%$.

7) Fuel costs are based on the price range of Heavy Fuel Oil (HFO) and Marine Diesel Oil (MDO). Referring to [24] dated 21 April 2017, HFO is within the minimum price range of $303 \mathrm{USD} /$ ton, most likely at $315 \mathrm{USD} /$ ton and a maximum of $323 \mathrm{USD} /$ ton. Whereas with reference to the MDO Bunker index of 14 June 2017, the MDO is in the minimum price range of $434 \mathrm{USD} / \mathrm{ton}$, most likely at $481 \mathrm{USD} /$ ton and maximum of 528 USD/ton.

By calculating the fuel cost requirements per year, fuel cost are estimated at a minimum value of $2,259,731$ USD/year, most likely at 2,466,793 USD/year and a maximum of 2,666,619 USD/year.

8) Port costs include mooring, landing, tugboat and guiding services. Referring to Pelindo I data, the estimated port cost is 15,189 USD/at port. The estimated port cost based on the estimated number of visits to the port per year is minimum $1,034,999$ USD/year, most likely 1,040,554 USD/year and maximum of 1,046,110 USD/year.

The estimated earnings value is based on the number of commissioning day and charter rate of the vessel. In addition, cost saving estimates also need to be taken into account. Explanation of each variable cost is as follows:

1) Commisioning day is the number of days that the ship will earn revenue for shipowners based on 
endurence estimates, estimated unwanted off-hire time i.e. 24 days per year [7], the loading and estimated for 30 days each time docking. The time ship is during endurence 7.35 days plus the time at the harbor for 7 days, so the time to take one around trip is 14.35 days/around trip. Minimum commissioning day estimation result is 326 days, most likely is 328 days and maximum is 330 days. Assuming the voyage distance 2,130 Nmiles in once around trip, then the average voyage number is 23 times in a year. So, the estimation of minimum commissioning day is 326 days, most likely is 328 days and the maximum is 330 days.

2) Charter rate is the amount of daily charter rate received by the ship owner from the charterer. This value is based on crude oil and product oil tanker earning 2015-2016 data from BIMCO, Clarksons [25], ie minimum estimate is 10,000 USD/day, most likely 23,000 USD/day and maximum 30,000 USD/day.

3) Bunkers cost saving is the amount of fuel cost savings resulting from the operation of the ship in a speed that is considered optimum. This value can be calculated by calculating the fuel requirements in some scenarios of ship service speed variation from 13.9 knots to 10 knots. This calculation should also consider earning loss to be smaller than the cost savings. The estimated cost unloading time of vessels at the port and docking each time for 2.5 years. Time for docking is of the minimum bunker cost saving is 1,040,988 USD/year, most likely at $1,136,375 \mathrm{USD} /$ year and a maximum of 1,228,429 USD / year.

4) Port charges saving is the magnitude of port cost savings resulting from the operation of the vessel at a speed that is considered optimum. This value is obtained by the same calculation as bunker cost saving. Estimated port charges saving minimum is $17,721 \mathrm{USD} /$ year, most likely $20,252 \mathrm{USD} /$ year and maximum 25,315 USD/year.

Because in calculations using bank loan scenarios, so the interest rate is also estimated. Interest rate or interest rate of bank which is estimated with reference to data of interest rate value from Bank Indonesia. Interest rate from 2005 to 2017 stated that the minimum value of $4.75 \%$ and maximum $12.75 \%$ with an average of $7.45 \%$ [26].

\section{Simulations Result}

The previous calculation states that scenario 1 is worth choosing. However, how well the probability of success of each scenario when executed is unknown. Therefore, to know its, Monte Carlo simulation was then adopted to obtain the CDFs of NPV, IRR, PP and PI. In order to achieve mean and variance stability, number of iterations was set at 10,000 .



Figure. 3. Cumulative Distribution Functions of NPV 
International Journal of Marine Engineering Innovation and Research, Vol. 1(4), Sept. 2017. 303-316 (pISSN: 2541-5972, eISSN: 2548-1479)

TABLE 8 .

STATISTIC DATA FROM NPV SiMULATION RESULT

\begin{tabular}{lccc}
\hline \multirow{2}{*}{ Statistic } & \multicolumn{3}{c}{ Value } \\
\cline { 2 - 4 } & Scenario 1 & Scenario 2 & Scenario 3 \\
\hline Mean & $5,629,700$ & $5,805,205$ & $5,981,896$ \\
\hline Median & $6,555,222$ & $6,686,650$ & $6,917,720$ \\
\hline Standard deviation & $9,814,970$ & $9,899,055$ & $10,043,528$ \\
\hline Skewness & -0.274 & -0.275 & -0.278 \\
\hline Kurtosis & 2.407 & 2.413 & 2.465 \\
\hline Minimum & $-20,778,700$ & $-21,937,752$ & $-27,235,132$ \\
\hline Maximum & $27,543,758$ & $28,604,553$ & $30,703,607$ \\
\hline
\end{tabular}

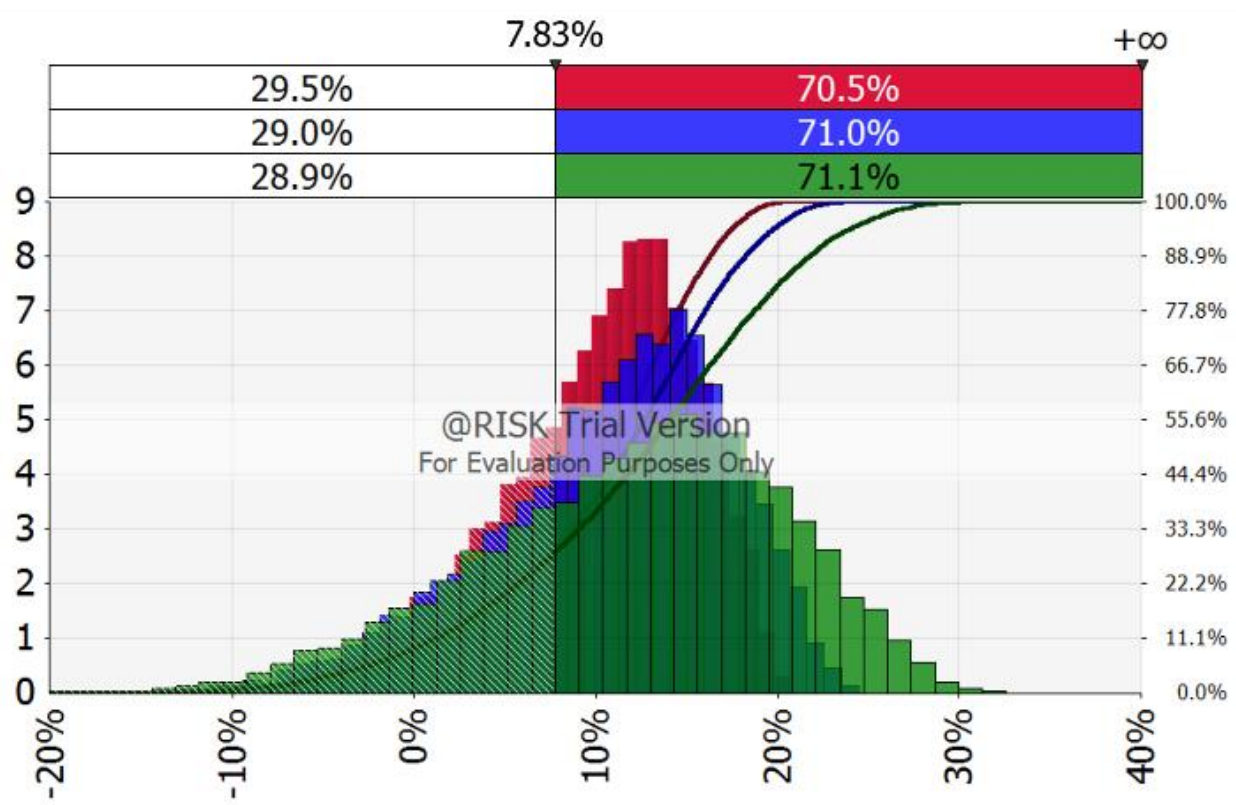

Figure. 4. Cumulative Distribution Functions of IRR

TABLE 9 .

STATISTIC DATA FROM IRR SimULATION RESUlT

\begin{tabular}{lccc}
\hline \multirow{2}{*}{ Statistic } & \multicolumn{3}{c}{ Value } \\
\cline { 2 - 4 } & Scenario 1 & Scenario 2 & Scenario 3 \\
\hline Mean & $11.523 \%$ & $12.443 \%$ & $14.114 \%$ \\
\hline Median & $12.358 \%$ & $13.300 \%$ & $14.903 \%$ \\
\hline Standard deviation & $5.129 \%$ & $6.188 \%$ & $8.002 \%$ \\
\hline Skewness & -0.626 & -0.550 & -0.355 \\
\hline Kurtosis & 2.971 & 2.860 & 2.643 \\
\hline Minimum & $-6.991 \%$ & $-8.990 \%$ & $-10.835 \%$ \\
\hline Maximum & $21.532 \%$ & $25.616 \%$ & $33.855 \%$ \\
\hline
\end{tabular}


International Journal of Marine Engineering Innovation and Research, Vol. 1(4), Sept. 2017. 303-316 (pISSN: 2541-5972, eISSN: 2548-1479)

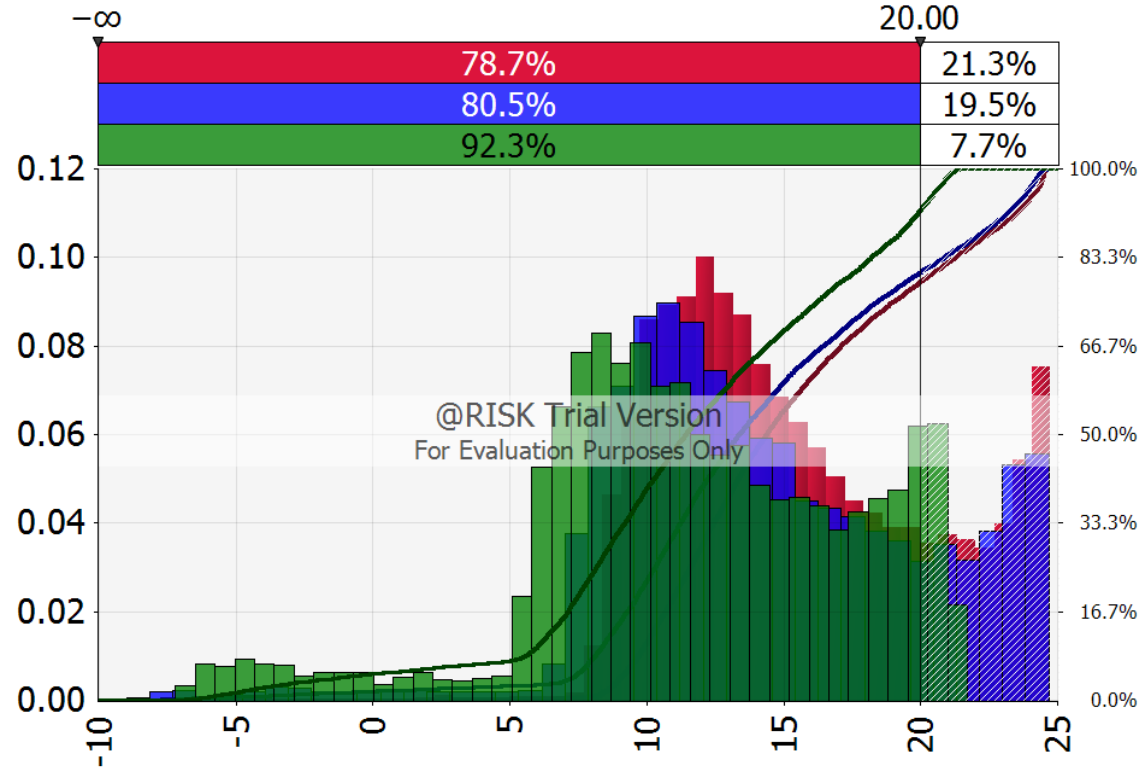

Figure. 5. Cumulative Distribution Functions of PP

Table 10

Statistic Data from PP Simulation Result

\begin{tabular}{lccc}
\hline \multirow{2}{*}{ Statistic } & \multicolumn{3}{c}{ Value } \\
\cline { 2 - 4 } & Scenario 1 & Scenario 2 & Scenario 3 \\
\hline Mean & 15.404 & 14.244 & 11.696 \\
\hline Median & 14.374 & 13.371 & 11.421 \\
\hline Standard deviation & 4.740 & 5.661 & 5.870 \\
\hline Skewness & 0.422 & -0.198 & -0.588 \\
\hline Kurtosis & 2.165 & 3.556 & 3.548 \\
\hline Minimum & -2.502 & -8.987 & -7.221 \\
\hline Maximum & 24.747 & 24.676 & 21.706 \\
\hline
\end{tabular}

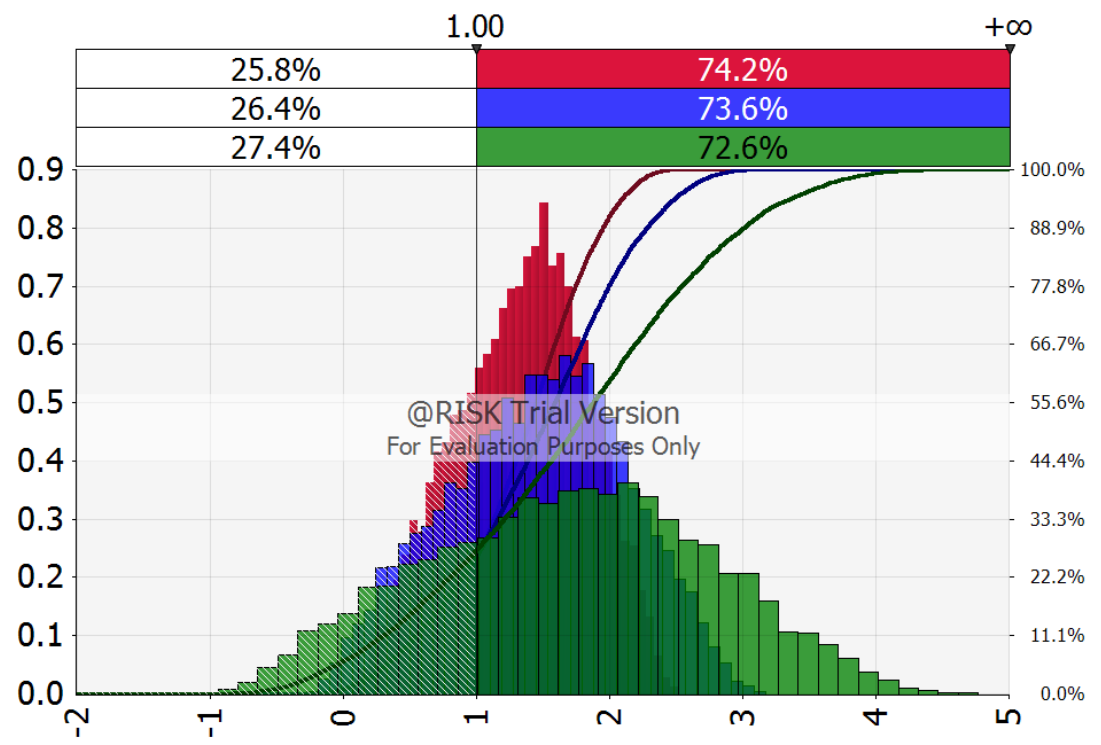

Figure. 6. Cumulative Distribution Functions of PI 
TABLE 11.

StATISTIC DATA FROM PI SimULATION RESUlT

\begin{tabular}{lrrr}
\hline \multirow{2}{*}{ Statistic } & \multicolumn{4}{c}{ Value } \\
\cline { 2 - 4 } & Scenario 1 & Scenario 2 & Scenario 3 \\
\hline Mean & 1.341 & 1.449 & 1.686 \\
\hline Median & 1.375 & 1.487 & 1.724 \\
\hline Standard deviation & 0.490 & 0.669 & 1.054 \\
\hline Skewness & -0.175 & -0.133 & -0.037 \\
\hline Kurtosis & 2.362 & 2.363 & 2.396 \\
\hline Minimum & 0.070 & -0.276 & -1.243 \\
\hline Maximum & 2.518 & 3.171 & 4.770 \\
\hline
\end{tabular}

\section{E. Sensitivity Analysis}

The sensitivity analysis results were obtained by use of relative function of @Risk software. Sensitivity analysis result for each criteria is present in table 14. From that result, interest rate and capital expenditure are most input variable which have negative correlation with NPV, IRR and PI. The annual interest rate will greatly affect the funding of the vessel project. This means that the ship owner needs to make a proper funding decision, the loan size and loan time, as this will greatly affect the feasibility of the project. As well as the CAPEX, it will greatly affect the project funding. Moreover, coupled with the construction of ships carried out in the domestic shipyard (Indonesia) where the cost of ship build will be more expensive when compared with shipbuilding abroad. In contrast, charter rate have positive correlation. With the decline in the value of the charter rate will be very sensitive to project feasibility parameters.

TABLE 12.

THE PROBABILITY OF ACEPPTANCE CRITERIA BASED ON MONTE CARLO SimUlation RESUlt

\begin{tabular}{llll}
\hline \multirow{2}{*}{ Acepptance criteria } & \multicolumn{3}{c}{ Probability } \\
\cline { 2 - 4 } & Scenario 1 & Scenario 2 & Scenario 3 \\
\hline Prob(NPV>0) & $71.3 \%$ & $72.1 \%$ & $72.1 \%$ \\
\hline Prob(IRR $>7,83 \%)$ & $70.5 \%$ & $71.0 \%$ & $71.1 \%$ \\
\hline Prob(PP<20) & $78.7 \%$ & $80.5 \%$ & $92.3 \%$ \\
\hline Prob(PI>1) & $74.2 \%$ & $73.6 \%$ & $72.6 \%$ \\
\hline
\end{tabular}

TABLE 13.

The VAlue of ACEPPTANCE CRITERIA

\begin{tabular}{lccc}
\hline \multirow{2}{*}{ Acepptance criteria } & \multicolumn{3}{c}{ Result } \\
\cline { 2 - 4 } & Scenario 1 & Scenario 2 & Scenario 3 \\
\hline NPV (USD) & $6,759,518$ & $10,813,703$ & $11,883,958$ \\
\hline IRR (\%) & $11.17 \%$ & $14.25 \%$ & $16.11 \%$ \\
\hline PP (year) & 14.46 & 11.82 & 10.65 \\
\hline PI & 1.384 & 1.779 & 2.166 \\
\hline
\end{tabular}


Table 14

Sensitivity Analysis Result

\begin{tabular}{|c|c|c|c|c|c|}
\hline \multirow{2}{*}{ No } & \multirow{2}{*}{ Input variables } & \multicolumn{4}{|c|}{ Correlation Value } \\
\hline & & NPV & IRR & $\mathbf{P P}$ & PI \\
\hline 1 & R1-probability & 0.00 & 0.00 & 0.00 & 0.00 \\
\hline 2 & R2-probability & -0.02 & -0.02 & 0.00 & -0.02 \\
\hline 3 & R3-probability & 0.00 & 0.00 & -0.01 & 0.00 \\
\hline 4 & R4-probability & 0.01 & 0.01 & 0.00 & 0.01 \\
\hline 5 & R5-probability & 0.00 & 0.00 & 0.00 & 0.00 \\
\hline 6 & R1-impact & 0.00 & 0.00 & -0.01 & 0.00 \\
\hline 7 & R2-impact & 0.00 & 0.00 & 0.01 & 0.00 \\
\hline 8 & R3-impact & -0.02 & -0.02 & 0.01 & -0.02 \\
\hline 9 & R4-impact & -0.01 & -0.01 & 0.00 & -0.01 \\
\hline 10 & R5-impact & 0.00 & 0.00 & 0.00 & 0.00 \\
\hline 11 & Capital Expenditure & -0.03 & -0.04 & 0.04 & -0.05 \\
\hline 12 & Crew cost & -0.01 & -0.01 & 0.02 & -0.01 \\
\hline 13 & Lubricating cost & 0.02 & 0.02 & -0.01 & 0.02 \\
\hline 14 & Repair \& maintenance cost & -0.02 & -0.02 & 0.01 & -0.02 \\
\hline 15 & Insurance cost & -0.02 & -0.02 & 0.02 & -0.02 \\
\hline 16 & Administration cost & 0.02 & 0.02 & -0.02 & 0.02 \\
\hline 17 & Docking cost & -0.02 & -0.02 & 0.02 & -0.02 \\
\hline 18 & Fuel cost & -0.05 & -0.05 & 0.02 & -0.05 \\
\hline 19 & Port charges & 0.00 & 0.00 & 0.01 & 0.00 \\
\hline 20 & Commisioning day & 0.02 & 0.02 & -0.01 & 0.02 \\
\hline 21 & Charter rate & 0.98 & 0.97 & -0.64 & 0.97 \\
\hline 22 & Bunker cost saving & 0.02 & 0.03 & 0.00 & 0.03 \\
\hline 23 & Port charges saving & 0.00 & 0.00 & 0.00 & 0.00 \\
\hline 24 & Interest rate & -0.17 & -0.20 & 0.13 & -0.19 \\
\hline
\end{tabular}

\section{CONCLUSION}

The simulation method especially Monte Carlo could be applied for financial feasibility of 17,500 LTDW Tanker project under risk and uncertainty. From the analysis, it can be concluded:

1) Risk of delays in delivery of new vessels risk of insufficient speed design, excessive fuel consumption, insufficient dead weight tonnage (DWT) and risk of tanker having off hire after a year delivery at very low level.

2) The 17,500 LTDW tanker investment project is feasible to run under funding decision of $100 \%$ of the company's own capital or by bank loan capital till $50 \%$.

3) Sensitivity analysis shown the interest rate and CAPEX are the most negative correlation, and charter rate is the most positive correlation with NPV, IRR and PI.

This study still limited in obtaining precise variable input data. Expert opinions and historical data review methods should be applied, not just referring to theoretical calculations. It is suggested that future research with different approaches to refine this research, firstly, determining PDFs of more precise input variables with near real data. Second, share the factors that influence the financial feasibility of the project by considering external risks, such as potential accidents, piracy and market potential. Third, despite the many limitations of technology and human resources, Indonesia's shipyard is not entirely weak. However, analysis to compare project implementation between domestic and international shipyard will be interesting to do.

\section{REFERENCES}

[1] A. Metelitsa and M. Mercer, "World Oil Transit Chokepoints Critical to Global Energy Security," 1 December 2014. [Online]. Available: http://www.eia.gov. [Accessed 26 March 2017].

[2] M. B. Zaman, E. Kobayashi, N. Wakabayashi and A. Maimun, "Risk of Navigation for Marine Traffic in the Malacca Strait using AIS," Procedia Earth and Planetary Science 14, p. 33 - 40, 2015.

[3] P. Sand, "Fleet Growth Squeezes Crude Oil Tanker Market," 22 December 2016. [Online]. Available: http://www.bimco.org. [Accessed 25 March 2017].

[4] H. Thanopoulau and S. P. Strandenes, "A Theoretical Framework for Analysing Long-term Uncertainty In Shipping," Case Studies on Transport Policy, 2017.

[5] P. Setyohadi, Model Manajemen Risiko Berbasis Respon Dinamis untuk Memitigasi Dampak Perubahan Regulasi Maritim: 
Perspektif Pemilik Kapal Tanker, Surabaya: Institut Teknologi Sepuluh Nopember, 2017.

[6] F. Celik, I. Erturk and E. Turan, "Investigation of Main Particulars Subject to Minimum Building Cost for Chemical Tankers," Ocean Engineering, p. 32- 37, 2013.

[7] M. Stopford, Maritime Economics 3rd Edition, London and New York: Routledge Taylor and Francis Group, 2009.

[8] T. E. Notteboom and B. Vernimmen, "The Effect of High Fuel Costs on Liner Service Configuration in Container Shipping," Journal of Transport Geography 17, p. 325-337, 2009.

[9] M. Basuki, D. Manfaat, S. Nugroho and A. Dinariyana, "Probabilistic Risk Assessment of The Shipyard Industry Using The Bayesian Method," International Journal of Technology, pp. 88-97, 2014.

[10] R. Flage, P. Baraldi, Z. Enrico and T. Aven, "Probability and Possibility Based Representations of Uncertainty in Fault Tree Analysis," Risk Analysis 33 (1), pp. 121-133, 2013.

[11] J. Liu, F. Jin, Q. Xie and M. Skitmore, "Improving Risk Assessment in Financial Feasibility of International Engineering Pojects: A Risk Driver Perspective," International Journal of Project Management 35, pp. 204-211, 2017.

[12] S. Grey, Practical Risk Assessment for Project Management, England: John Wiley \& Sons Ltd, 1995.

[13] M. Marseguerra and E. Zio, "Monte Carlo Simulation for ModelBased Fault Diagnosis in Dynamic System," Reliab. Eng. Syst. Saf. 94 (2), pp. 180-186, 2009.

[14] R. Obermaier, "Risk Analysis in Investment Appraisal based on the Monte Carlo Simulation Technique," European Physical Journal B 30, p. 407-409, 2002.

[15] D. Priyanta, "The Development of Equipment Criticality Analysis (ECA) Protocols of Offshore Carbon Steel Static Mechanical Equipment," Asian Journal of Applied Sciences, p. 1258 - 1266, 2016.

[16] D. Priyanta, Keandalan dan Perawatan, Surabaya: ITS, 2000.

[17] J. Mun, Modeling Risk: Applying Monte Carlo Simulation, Real Options Analysis, Forecasting, and Optimization Techniques, Canada: John Wiley \& Sons, Inc., Hoboken, New Jersey, 2006.

[18] C. Maio, C. Schexnayder, K. Knutson and S. Weber, "Probability Distribution Functions for Construction Simulation," Journal of Construction Engineering and Management 126(4), pp. 285-292, 2000.
[19] I. Soeharto, Manajemen Proyek (dari konseptual sampai operasional) Jilid 2, Jakarta: Erlangga, 2001.

[20] D. Vose, Quantitative Risk Analysis: A Guide to Monte Carlo Simulation Modelling, Chichester: Wiley, 2000.

[21] T. S. C. F. R. M. Saltelli A, Sensitivity Analysis in Practice: A Guide to Assessing Scientific Models, New York: Wiley, 2004.

[22] K. B. Odland, Risk Management in Shipbuilding Projects Using Monte Carlo Simulation for Scheduling, Norwegia: Norwegian University of Science and Technology, 2014.

[23] PT. Pertamina (PERSERO) Shipping, "Document," PT. Pertamina (PERSERO) Shipping, Jakarta, 2013.

[24] Ship \& Bunker, "News and intelligence for the marine fuels industri," 21 April 2017. [Online]. Available: http://shipandbunker. [Accessed 24 April 2017].

[25] P. Sand, "Tanker Shipping: a Strong Season Lifts Crude Oil Tanker Before It is Expected to Hit the Fan in 2017," 30 Januari 2017. [Online]. Available: http://www.bimco.org.

[26] J. Taborda, "Indonesia Interest Rate ," 15 Juni 2017. [Online]. Available: https://tradingeconomics.com/indonesia/interest-rate [Accessed 16 Mei 2017].

[27] P. L. Chu, C. Vanderghem, H. L. MacLean and B. A. Saville, "Financial Analysis and Risk Assessment of Hydroprocessed Renewable Jet Fuel Production from Camelina, Carinata and Used Cooking Oil," Applied Energy xxx, p. xxx-xxx, 2016.

[28] S. S. Saffie and S. H. Jaaman, "Monte Carlo on Net Present Value for Capital Investment in Malaysia," Procedia - Social and Behavioral Sciences 219, p. 688-693, 2016.

[29] B. Amigun, D. Petrie and J. Görgens, "Economic Risk Assessment of Advanced Process Technologies for Bioethanol Production in South Africa: Monte Carlo Analysis," Renewable Energy 36, pp. 3178-318 6, 2011.

[30] Pitana T, Gurning Saut, Fikri F. "Modelling of LPG Ship Distribution in Western of Indonesia using Discrete Simulation Method ". International Journal of Marine Engineering Innovation and Research., vol. 1, no. 3, Jun. 2017

[31] Santoso A, Zaman B Z, Prawira A Y Techno -economic Analysis of Rotor Flettner in Container Ship 4000DWT ". International Journal of Marine Engineering Innovation and Research., vol. 1, no. 3, Jun. 2017 